\title{
Identification and Modulation of a G rowth Hormone-Binding Protein in Rainbow Trout (Oncorhynchus mykiss) Plasma during Seawater Adaptation
}

\author{
Frédéric Sohm, ${ }^{*} \uparrow$ Isabelle Manfroid, $\uparrow \ddagger$ Alain Pezet, $\dagger$ \\ Françoise Rentier-Delrue, $\uparrow$ Mariann Rand-Weaver, $\S$ Paul A. Kelly, $\uparrow$ \\ Gilles Boeuf, $\uparrow$ Marie-C atherine Postel-Vinay, $\uparrow$ Amaury de Luze, ${ }^{*}, \dagger$ \\ and Marc Ederyt, 1
}

\begin{abstract}
†U nité 344, Endocrinologie moléculaire, Institut National de la Santé et de la Recherche M édicale, Faculté de M édecine N ecker, 75730 Paris Cedex 15, France; łLaboratory of M olecular Biology and Genetic Engineering, Université de Liège, 4000 Sart-Tilman, Belgium; §D epartment of Biology and Biochemistry, Brunel U niversity, U xbridge, Middlesex UB8 3PH, England; IInstitut Français de la Recherche et d'Exploration de la Mer, Brest, BP 70, 29280 Plouzane, France; and * Laboratoire de Physiologie G énérale et Comparée, M uséum National d'Histoire N aturelle, Unité de Recherche Associée 90, Centre National de la Recherche Scientifique, 75231 Paris Cedex 05, France
\end{abstract}

Accepted April 29, 1998

A soluble protein that specifically bound 125I-human growth hormone (hG H) was identified in rainbow trout plasma, using HPLC-gel filtration. The binding affinity of the protein for hGH was $1.2 \times 10^{9} \mathrm{M}^{-1}$. 125/-rainbow trout GH (tG H) was also able to bind to the protein albeit with a lower affinity $\left(6.6 \times 10^{7} \mathrm{M}^{-1}\right)$ than $\mathrm{hGH}$. Crosslinking experiments using ${ }^{125} \mathrm{I}-\mathrm{hGH}$ revealed two specific bands of 150 and $130 \mathrm{kDa}$. The complex ${ }^{125 /-h G H-B P}$ could be precipitated by a monoclonal anti-GH receptor antibody, suggesting a close relationship between the plasma GH-BP and the GH receptor. A fourfold increase in the hGH binding to the $\mathrm{GH}-\mathrm{BP}$ was shown $48 \mathrm{~h}$ after transfer of the fishes from freshwater to seawater. The increase in binding was related to a high binding capacity without significant changes in binding affinity. These results suggest a potential role of this related GH-BP as an index of $\mathbf{G H}$ effects during seawater adaptation in salmonids.

๑ 1998 Academic Press

Key Words: salmonid; growth hormone; somatolactin; receptor; binding protein; osmoregulation.

\footnotetext{
${ }^{1}$ To whom reprint request should be addressed.

2 Abbreviations used: GH, growth hormone; PRL, prolactin; SL, somatolactin; GH-BP, GH-binding protein.
}

Growth hormone $(\mathrm{GH})^{2}$ and prolactin (PRL), with somatolactin (SL) in fish and placental lactogen in mammals, belong to the same family of hormonal peptides (Rand-Weaver and Kawauchi, 1993). The major functions of $\mathrm{GH}$ in all species studied are control of metabolism and growth of skeletal and soft tissues. In salmonids, it is now established that GH enhances survival and improves hypoosmoregulatory ability during seawater adaptation (Clarke et al., 1977). The hypoosmoregulatory effect of $\mathrm{GH}$ in seawater is independent of its growth promoting effect (Collie et al., 1989). In teleost fishes, as in other vertebrates, the mechanism of $\mathrm{GH}$ action involves $\mathrm{GH}$ binding to membrane receptors. Few data are available concerning functional interactions between $\mathrm{GH}$ and its receptor in fish. It has been suggested that the homodimerization of $\mathrm{GH}$ receptor is a characteristic both in mammals and in fishes (Calduch-Giner et al., 1997). $\mathrm{GH}$ receptors are present in many organs and most abundantly in the liver (Gray et al., 1990). To assess the target organs for $\mathrm{GH}$ in salmonids, a homologous radioreceptor assay for $\mathrm{GH}$ was established for coho salmon and rainbow trout (Sakamoto and Hirano, 1991; Yao et al., 1991). In the trout, GH receptors were 
identified in liver, gill, intestine, and posterior kidney. Scatchard analysis showed the presence of a single class of GH receptors characterized by high affinity and low capacity. The number of receptors in the gill, intestine, and kidney was about $3-6 \%$ of that in the liver (Sakamoto and Hirano, 1991). These results indicate that liver and osmoregulatory organs are potential targets for GH actions. Receptor numbers in the liver increased after transfer to seawater, suggesting the likehood of at least partial mediation by the liver of the osmoregulatory actions of GH (Sakamoto and Hirano, 1991). An interaction of one or more factors, such as hormonal and nutritional status, in association with GH receptor turnover may occur, contributing to the successful adaptation of salmonids to the marine environment.

In mammals, a soluble form of the GH receptor has been identified (Baumann, 1991). The growth hormonebinding protein (GH-BP) which represents the extracellular domain of the GH receptor (Leung et al., 1987). Serum GH-BP has been identified in numerous domestic animals, from poultry to mammals (Davis et al., 1992). Regulation of the expression of GH-BP appears to be also under the control of multiple hormonal, nutritional, or environmental factors, although its biological function remains to be clarified (Postel-Vinay, 1996).

A soluble protein has been identified in rainbow trout (Oncorhynchus mykiss) plasma which specifically binds human $\mathrm{GH}(\mathrm{hGH})$ with higher affinity and lower capacity than the homologous rainbow trout $\mathrm{GH}$ (tGH). Circulating GH-BP was identified in both freshwater- and seawater-adapted trout. During seawater adaptation a fourfold increase in GH-binding capacity occurred (48 $\mathrm{h}$ after transfer), declining thereafter. Thus, judged by the binding of labeled hGH to circulating GH-BP, the present data provide new avenues to study GH effects at the receptor level and its potential involvement during seawater adaptation in salmonids.

\section{MATERIALS AND METHODS}

\section{Animals and Blood Sampling}

Immature yearling rainbow trout (O. mykiss) weighing 280-320 g were obtained from the Cornec fish farm hatchery (Brest, France) and transported to the IFREMER station (Brest). They were maintained in
Swedish tanks $(2 \times 2 \times 1 \mathrm{~m})$ containing 2000 liters of running freshwater at $12-13^{\circ} \mathrm{C}$, under natural photoperiod, for 2-3 weeks before study (April 1996). Fish were starved $24 \mathrm{~h}$ before seawater transfer. Otherwise, fish were fed a ration of $1.5 \%$ body wt/day with commercial trout moist pellet, using an automatic feeder. Rainbow trout were transferred to seawater replacing the freshwater with a seawater supply into the tank, reaching full seawater condition (salinity: $35.5 \%$ ) within half an hour. After decapitation of unanesthetized fish, they were weighed and blood samples were collected from the dorsal aorta into heparinized tubes. The samples were centrifuged $\left(4^{\circ} \mathrm{C}\right)$ at $3000 \mathrm{~g}$ for $10 \mathrm{~min}$, and the plasma was aliquoted and stored at $-20^{\circ} \mathrm{C}$ until assayed.

\section{Materials}

Recombinant hGH was obtained from Serono Laboratories (Boulogne, France), ovine PRL (oPRL) was from NIDDK-16, National Hormone and Pituitary Program (Bethesda, MD), bovine GH (bGH) was from W. Baumbach, American Cyanamid Corporation (Princeton, NJ), recombinant trout GH (tGH) was from Pharos (Belgium) according to Rentier-Delrue et al. (1989a), recombinant rainbow trout PRL (tPRL) was according to Mercier et al. (1989), recombinant tilapia GH (tiGH) was according to Rentier-Delrue et al. (1989b), rainbow trout somatolactin (tSL) was according to Rand-Weaver et al. (1991), and tilapia PRL was according to Swennen et al. (1991).

Carrier-free ${ }^{125} \mathrm{I}-\mathrm{Na}$ was purchased from Amersham International (Buckinghamshire, UK), disuccimidyl suberate (DSS) and Iodogen were from Pierce (Rockford, IL), and protein PAK $300 \mathrm{sw}$ column was from Waters (Milford, MA). Iodination of hGH was performed using Chloramine-T (Lesniak et al., 1973). ${ }^{125} \mathrm{I}-\mathrm{tGH}$ was obtained by the Iodogen method (Salacinski et al., 1981). Labeled hormones were purified on Sephadex G75 column and eluted with $0.1 \%$ bovine serum albumin/0.05 M phosphate buffer, $\mathrm{pH}$ 7.5. Specific activities of radiolabeled hormones ranged from 80 to $140 \mu \mathrm{Ci} / \mu \mathrm{g}(2.96-5.18 \mathrm{MBq} / \mu \mathrm{g})$.

\section{GH-Binding Protein Assays}

GH-binding activity in plasma was measured as described by (Tar et al., 1990). Briefly, after filtration 
through 0.45-mm Millipore minifilters, different volumes of plasma were incubated for $20 \mathrm{~h}$ at $4^{\circ} \mathrm{C}$ in $100 \mu \mathrm{l}$ of $0.1 \%$ bovine serum albumin/ $0.1 \mathrm{M}$ phosphate buffer, $\mathrm{pH} 7.0$, containing $1 \times 10^{5} \mathrm{cpm}\left[{ }^{125} \mathrm{I}\right] \mathrm{hGH}\left(16 \mathrm{~h}\right.$ at $\left.4^{\circ} \mathrm{C}\right)$ or $\left[{ }^{125} \mathrm{I}\right] \mathrm{tGH}\left(3 \mathrm{~h}\right.$ at $\left.20^{\circ} \mathrm{C}\right)$ in the absence or presence of various concentrations of unlabeled GH. These incubation conditions were determined in preliminary experiments as giving the highest binding level for hGH and $\mathrm{tGH}$, respectively, and they did not affect the affinity. Elution was performed isocratically using a degassed buffer (0.1 M, $\mathrm{Na}_{2} \mathrm{SO}_{4} / 0.1 \mathrm{M}$ phosphate buffer, $\left.\mathrm{pH} 7.0\right)$ pumped at a rate of $0.5 \mathrm{ml} / \mathrm{min}$. Radioactivity was recorded on line by using a Berthold LB 504 gamma detector connected to a computer. The binding of labeled GH is expressed as the radioactivity in peak I divided by the total radioactivity (peaks I + II): I (125I-GH-BP), II (free $\left.{ }^{125} \mathrm{I}-\mathrm{GH}\right)$. Scatchard analyses were performed using the program Ligand (Munson and Rodbard, 1980).

\section{Cross-Linking Experiments}

Cross-linking of ${ }^{125} \mathrm{I}-\mathrm{hGH}$ to the plasma trout $\mathrm{GH}-$ binding protein was achieved as follows: a $50-\mu 1$ aliquot of plasma was incubated with ${ }^{125} \mathrm{I}-\mathrm{hGH}\left(10^{6}\right.$ cpm) in $25 \mathrm{mM}$ phosphate buffer, $\mathrm{pH} 7.4$ (final volume, $65.5 \mu \mathrm{l})$. Parallel incubations were performed with an excess $(2 \mu \mathrm{g})$ of native hGH. After $12 \mathrm{~h}$ at $4^{\circ} \mathrm{C}$, disuccinimidyl suberate in dimethyl sulfoxide was added at a final concentration of $0.5 \mathrm{mM}$. After $15 \mathrm{~min}$ at room temperature, $7 \mu \mathrm{l}$ of $1 \mathrm{M}$ Tris- $\mathrm{HCl}, \mathrm{pH} 6.8$, was added. Sample buffer, containing 2-mercaptoethanol (5\% final) and SDS (1\% final), was added to the mixture. Half of each sample $(50 \mu \mathrm{l})$ was heated for 5 min at $100^{\circ} \mathrm{C}$ and resolved by $7 \%$ SDS/PAGE along with prestained $M_{\mathrm{r}}$ standards under reducing conditions by the procedure of Laemmli (1970). Gels were dried and scanned using a PhosphorImager (Molecular Dynamics).

\section{Immunoprecipitation of G H-BP}

Trout plasma samples $(200 \mu \mathrm{l})$ were incubated with ${ }^{125} \mathrm{I}-\mathrm{hGH}\left(2 \times 10^{5} \mathrm{cpm}, 300 \mu \mathrm{l}\right)$ in the presence or absence of unlabeled $\mathrm{hGH}$ in $0.1 \%$ bovine serum albumin/25 mM Tris, pH 7.5/10 $\mathrm{mM} \mathrm{MgCl}_{2}$. After $16 \mathrm{~h}$ at $22^{\circ} \mathrm{C}, 1 \mu \mathrm{g} / 1 \mu \mathrm{l}$ monoclonal antibody (mAb 263) directed against the extracellular domain of GH-R
(Biogenosis, Barnard et al., 1985) was added to the medium, and incubation was continued for an additional $5 \mathrm{~h}$. Five-hundred microliters of $\gamma$-globulin $(0.1 \%)$ and $25 \%(\mathrm{v} / \mathrm{v})$ polyethylene glycol (final concentration $12.5 \%$ ) in $25 \mathrm{mM}$ phosphate buffer, $\mathrm{pH} 7.4$, was added. As a positive control, rabbit hepatic membranes were used. The membranes were diluted in 25 $\mathrm{mM}$ Tris buffer, $\mathrm{pH} 7.4 / 2.5 \%$ Triton $\mathrm{X}-100$ at final protein concentration of $6 \mathrm{mg} / \mathrm{ml}$. After centrifugation for $30 \mathrm{~min}$ at $15,000 \mathrm{~g}, 200 \mu \mathrm{l}$ of the supernatant (solubilized receptor) was incubated respectively with labeled hGH and mAb263 as described for trout plasma. The tubes were centrifuged, the supernatant was discarded, and the radioactivity of the pellet was measured in an LKB counter.

\section{Statistics}

Statistical analysis of the results was based on the Duncan's multiple range test, comparing experimental groups. Results are expressed as means \pm SEM.

\section{RESULTS}

\section{Characterization of GH-BP in Trout Serum}

The elution profile of labeled ${ }^{125} \mathrm{I}-\mathrm{hGH}$ incubated with $2 \mu$ plasma of rainbow trout is shown in Fig. 1A. Two peaks (I and II) were identified. Peak I (20\% of total radioactivity) represents the complex of ${ }^{125} \mathrm{I}-\mathrm{hGH}-$ binding protein. The elution time of the radioactive peak occurred at $14 \mathrm{~min}$. This peak is abolished by an excess $(1 \mu \mathrm{g})$ of native hGH used to calculate the non specific binding (Fig. 1A). Peak II consisted of free ${ }^{125} \mathrm{I}-\mathrm{hGH}$. Specific binding of ${ }^{125} \mathrm{I}-\mathrm{hGH}$ increased from 10 to $70 \%$ of the total radioactivity with plasma volumes from 1 to $25 \mu$ l. Fifty percent inhibition of ${ }^{125} \mathrm{I}-\mathrm{hGH}$ binding to the BP was obtained with 2 $\mathrm{ng}$ /incubation of hGH (Fig. 2A). Competition with homologous or heterologous hormones showed that only tGH competed with ${ }^{125} \mathrm{I}-\mathrm{hGH}$ with a low apparent affinity $\left(\mathrm{IC}_{50}=0.75 \mu \mathrm{g} /\right.$ incubation $)$. Very limited competition was observed with $\mathrm{tSL}\left(\mathrm{IC}_{50}=20 \mu \mathrm{g} /\right.$ incubation). No inhibition was detected with excess $(50 \mu \mathrm{g})$ tPRL, tiPRL ${ }_{177}$ and tiPRL ${ }_{188}$, oPRL, tiGH, or bGH (Fig. 2A). No binding of ${ }^{125} \mathrm{I}-\mathrm{oPRL}$ was observed after 
incubation with either 2 or $50 \mu$ of serum (data not shown). The affinity and the capacity of the GH-BP for ${ }^{125} \mathrm{I}-\mathrm{hGH}$ as evaluated by Scatchard plot analysis are $1.2 \times 10^{9} \mathrm{M}^{-1}$ and $3.48 \times 10^{-10} \mathrm{M}$, respectively (Fig. 2A).

A similar HPLC elution profile was observed when 2 $\mu \mathrm{l}$ of plasma was incubated with ${ }^{125} \mathrm{I}-\mathrm{tGH}$ (Fig. 1B). This peak is abolished by an excess $(1 \mu \mathrm{g})$ of native $\mathrm{hGH}$ (data not shown), indicating that $\mathrm{tGH}$ and $\mathrm{hGH}$ probably bind to the same molecular size BP in rainbow trout serum. Complete inhibition of ${ }^{125} \mathrm{I}-\mathrm{tGH}$ binding was obtained using $50 \mu \mathrm{g}$ of unlabeled $\mathrm{tGH}$ with $\mathrm{IC}_{50}=20 \mu \mathrm{g} /$ incubation. Characteristics of $\mathrm{tGH}$ binding estimated by Scatchard plot analysis, confirmed the low affinity and the high capacity (Fig. 2B).

Evaluation of GH-BP molecular weight of cross-

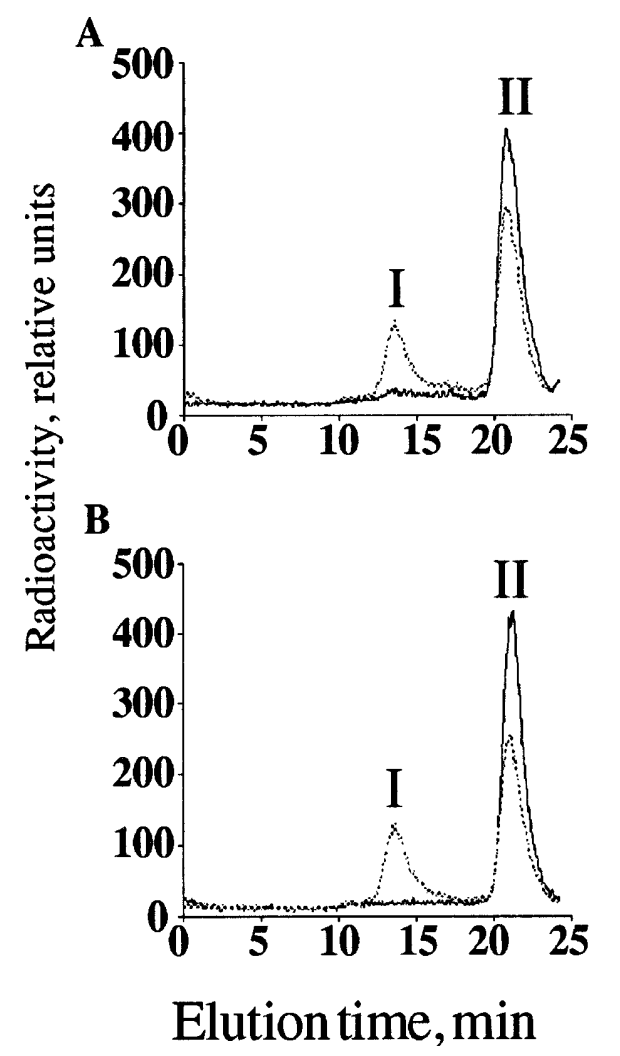

FIG. 1. Elution profile from HPLC-gel filtration column of ${ }^{125} \mathrm{I}-\mathrm{hGH}$ (A) and ${ }^{125} \mathrm{I}-\mathrm{tGH}$ (B) incubated with $2 \mu \mathrm{l}$ of rainbow trout plasma. Incubations were performed in the absence (thin line) or presence of $1 \mu \mathrm{g} \mathrm{hGH}$ or $50 \mu \mathrm{g}$ of $\mathrm{tGH}$ (thick line). The elution times of complexed ${ }^{125} \mathrm{I}-\mathrm{hGH}-\mathrm{BP}(\mathrm{A})$ or ${ }^{125} \mathrm{ItGH}-\mathrm{BP}$ (B) (peak I) was 14 and 21 min for ${ }^{125} \mathrm{I}-\mathrm{hGH}$ (A) or ${ }^{125} \mathrm{ItGH}$ (B) (peak II). For ${ }^{125} \mathrm{I}-\mathrm{hGH}$, total binding and nonspecific binding were 21 and $4 \%$, respectively (A).
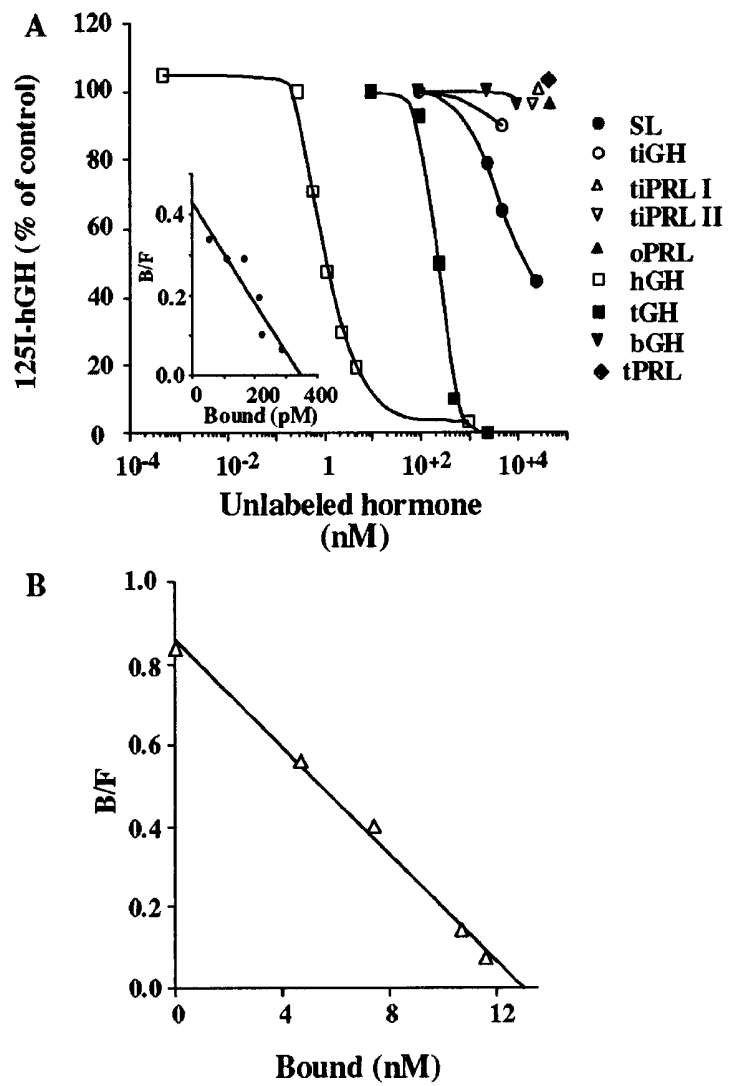

FIG. 2. Effects of increasing concentrations of $t G H, t P R L, t S L$, oPRL, hGH, bGH, tiGH, and tiPRLs on the binding of ${ }^{125} \mathrm{I}-\mathrm{hGH}$ to rainbow trout plasma (A) and representative Scatchard plots of competition binding experiments with ${ }^{125} \mathrm{I}-\mathrm{hGH}(\mathrm{A})$ and ${ }^{125} \mathrm{I}-\mathrm{tGH}$ (B). (A) $2 \mu$ of plasma from rainbow trout transferred for 2 days in seawater was incubated for $20 \mathrm{~h}$ at $4^{\circ} \mathrm{C}$, in the absence or presence of increasing concentrations of unlabeled homologous or heterologous hormones. The binding of ${ }^{125} \mathrm{I}-\mathrm{hGH}$ is expressed as the percentage of the maximal binding. The results are from one representative experiment, repeated two times, and are the mean of duplicate determinations. Maximal binding was $20 \%$ of radioactivity. (Inset) One representative Scatchard plot of competition binding experiment with ${ }^{125} \mathrm{I}-\mathrm{hGH}$ from rainbow trout transferred for 2 days in seawater. The affinity and capacity are, respectively, $1.23 \times 10^{9} \mathrm{M}^{-1}$ and $3.48 \times 10^{-10} \mathrm{M}$. (B) Scatchard plot of competition binding experiment in plasma from rainbow trout transferred for 2 days in seawater. The $K_{\mathrm{a}}$ and $B_{\max }$ are $6.6 \times 10^{7} \mathrm{M}^{-1}$ and $1.3 \times 10^{-8} \mathrm{M}$, respectively.

linked ${ }^{125} \mathrm{I}-\mathrm{hGH}-\mathrm{BP}$ was performed by SDS/PAGE under reducing conditions (Fig. 3). Two bands corresponding respectively to complexes of 150 and 130 $\mathrm{kDa}$ (lane 1) were revealed. Both are specific, since they were inhibited when an excess of native hGH was added (lane 2). No inhibition was observed with $2 \mu \mathrm{g}$ 
tPRL, tSL, or tGH (data not shown). To better characterize the tGH-BP, immunoprecipitation studies were carried out using a monoclonal antibody against the $\mathrm{GH}$ receptor (mAb263). The antibody immunoprecipitated the complex hGH/GH-BP (20.3\% of total radioactivity was immunoprecipitated). These results suggest a close immunological relationship between the membrane GH receptor and the trout plasma GH-BP.

\section{Transfer to Seawater}

All studies were performed using ${ }^{125} \mathrm{I}-\mathrm{hGH}$ as a ligand for plasma GH-BP. A fourfold increase in GH binding activity $(P<0.01)$ was observed in the plasma of rainbow trout $48 \mathrm{~h}$ after transfer into seawater (Fig. $4 \mathrm{~A})$. This increase is related to a greater binding

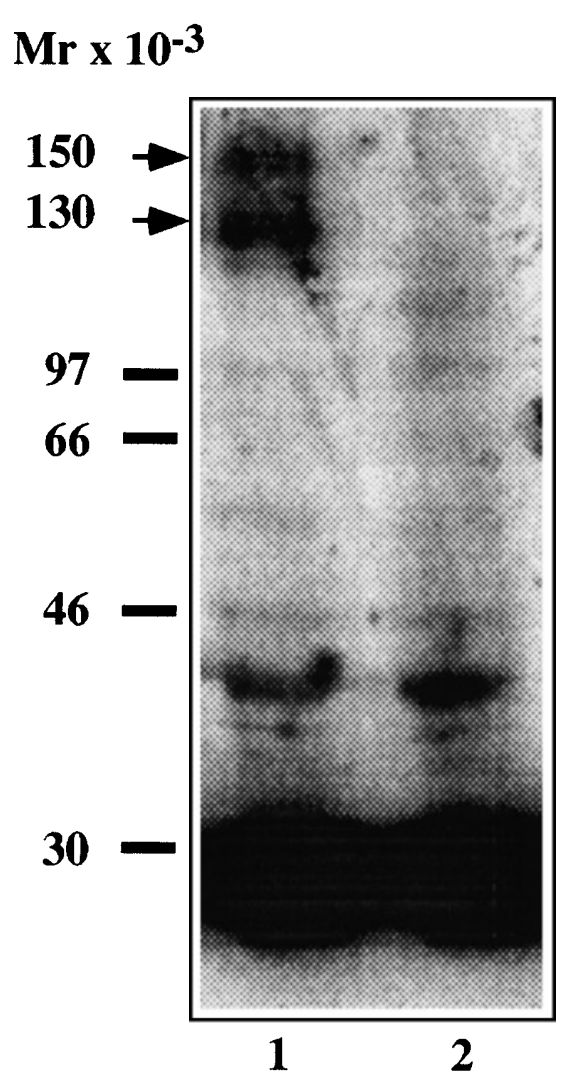

FIG. 3. Autoradiograph of PAGE showing cross-linking of ${ }^{125} \mathrm{I}-$ $\mathrm{hGH}-\mathrm{BP}$ in $25 \mu \mathrm{l}$ of plasma from freshwater rainbow trout incubated in the absence (lane 1) or presence (lane 2) of $2 \mu \mathrm{g} \mathrm{hGH}$. Electrophoresis was performed under reducing conditions. Markers of MW standards are indicated by lines $\left(M_{\mathrm{r}} \times 10^{-3}\right)$. Arrows indicate the position of specific radiolabeled proteins.

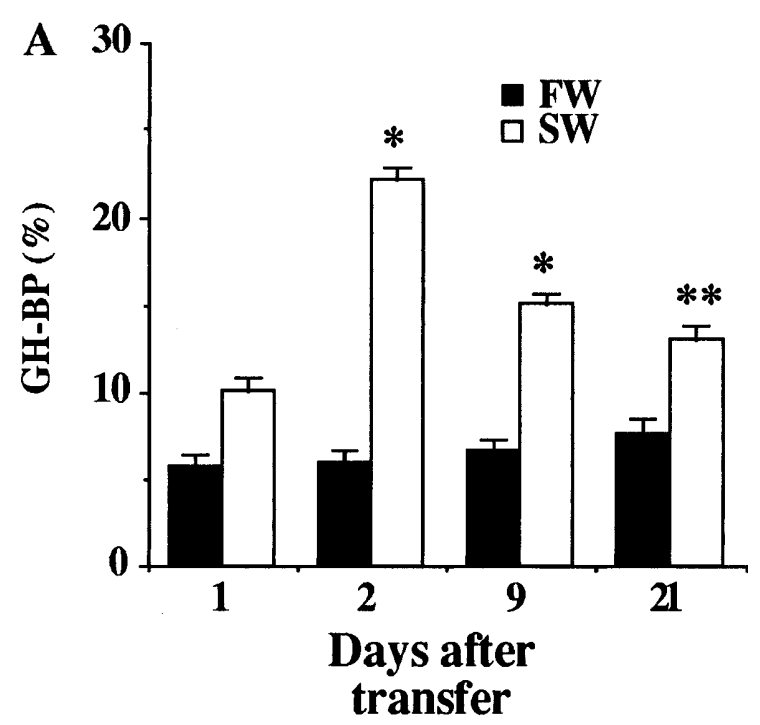

B

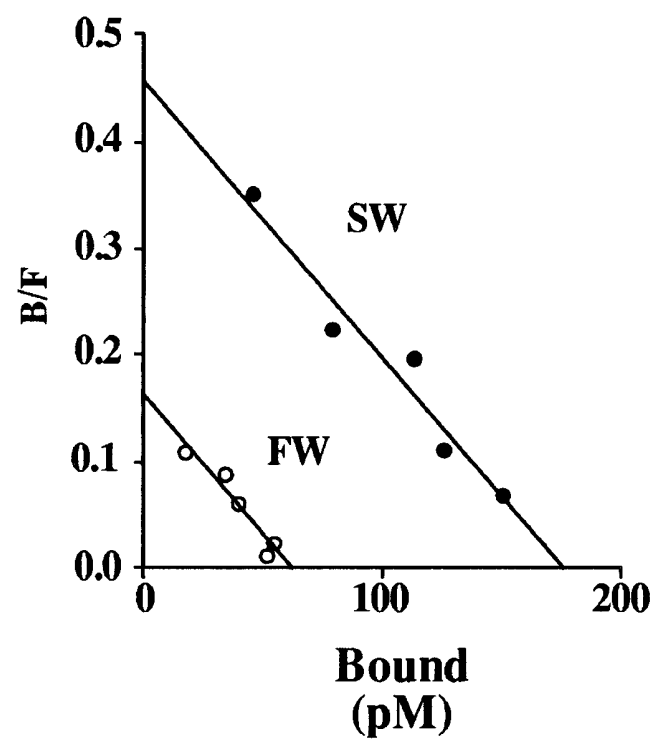

FIG . 4. Time-dependent change of ${ }^{125} \mathrm{I}-\mathrm{hGH}$ binding to $\mathrm{BP}(\mathrm{A})$ and representative Scatchard plots of competition binding experiments with ${ }^{125} \mathrm{I}-\mathrm{hGH}(\mathrm{B})$ in rainbow trout transferred from freshwater (FW) to seawater (SW). Control fishes (open columns or circles) were compared to transferred fish in seawater (closed columns or circles). (A) GH-BP level is expressed as percentage of specific binding of ${ }^{125} \mathrm{I}-\mathrm{hGH}$ per $2 \mu \mathrm{l}$ plasma. Vertical bars represent SEM $(n=8)$. ${ }^{*} P<$ 0.01 and ${ }^{* *} P<0.05$ compared with both the initial (day 0 ) and the control fishes transferred in freshwater; (B) representative Scatchard plot experiments using plasma from freshwater (FW) rainbow trout transferred for 2 days and seawater (SW) rainbow trout transferred for 2 days. The $K_{\mathrm{a}}$ and $B_{\max }$ in serum from freshwater control are $1.82 \times 10^{9} \mathrm{M}^{-1}$ and $7.7 \times 10^{-11} \mathrm{M}$. The $K_{\mathrm{a}}$ and $B_{\max }$ using plasma from rainbow trout transferred for 2 days in seawater are, respectively, $2.6 \times 10^{9} \mathrm{M}^{-1}$ and $1.76 \times 10^{-10} \mathrm{M}$. 
capacity as shown in Fig. 4B. The level of GH-BP in plasma of rainbow trout fully adapted to seawater (3 weeks after transfer) was twice $(P<0.05)$ the level found in plasma of freshwater-adapted fish. Although the increase in hGH binding to BP from trout transferred into SW is associated with an increased binding capacity, there is no significant change in binding affinity (FW, $1.69 \pm 0.13 \times 10^{9} \mathrm{M}^{-1}, n=4$; SW, $2.09 \pm 0.18 \times 10^{9} \mathrm{M}^{-1}, n=4$; Fig. 4B).

\section{DISCUSSION}

The present study identifies a binding protein with high affinity for hGH in rainbow trout plasma; tGH and $\mathrm{tSL}$ appeared to be weak competitors for ${ }^{125} \mathrm{I}-\mathrm{hGH}$ binding. No displacement was observed with bGH or tiGH; however, hGH is known to behave as a more potent somatogenic ligand than other GHs for GHBPs. Also, no displacement was observed with tPRL, ti$\mathrm{PRL}_{177}$, tiPRL ${ }_{188}$, or oPRL, suggesting that the BP has no prolactin like activity. Thus, considering the homologous hormones, these binding properties appear to be more related to a putative circulating GH-BP. Similar data with higher binding affinity of heterologous hormones for the GH-BP compared with homologous GH (approximately 100-fold) has been reported in chicken and other domestic animals (Davis et al., 1992). Mutational and structural studies have demonstrated that one hGH molecule binds to two molecules of hGHBP, through two regions called binding sites 1 and 2 (Goffin et al., 1996). Binding site 1 is delimited by a pocket encompassed within helix 1 , helix 4 , and loop 1 (Fig. 5), whereas binding site 2 is delimited by the opposite site of helix 1 and 3 as well as four residues of the $\mathrm{N}$ terminus.

Of the 25 residues identified in hGH as hGHBP binding site 1 determinants (Cunningham and Wells, 1989), 16 are substituted in the $\mathrm{tGH}$; among them 12 are nonconservative substitutions. In helix 4 , which contains the most important determinants of binding site 1, five residues of the hGH (Y164, D171, F176, R178, and V185) present such nonconservative substitutions in the $\mathrm{tGH}$ (Fig. 5). This would imply that $\mathrm{tGH}$ binding site 1 is different from hGH binding site 1 . Based on hGH/hGHBP model and since the structure of the tGHR or tGHBP are not known, a working hypothesis might be that site 1 of $\mathrm{tGH}$ has a reduced activity to bind to GHBP than hGH site 1, thus resulting in a decreased affinity of $\mathrm{tGH}$ site 1 relative to hGH site 1 for GHBP. Of interest is the limited competition by $\mathrm{tSL}$ for hGH binding suggesting that tSL possibly also binds to a membrane receptor belonging to the PRL/GH receptor family. Indeed, no information is available on the type of receptor used by tSL or the physiological role of this hormone in fish (RandWeaver and Kawauchi, 1993).

In mammals, there is an amino acid sequence identity between the extracellular domain of the membrane GH receptor and the serum GH-BP (Leung et al., 1987). GH-BP is a short soluble form of the GH receptor. Serum GH-BP binds to circulating $\mathrm{GH}$ forming a high-affinity complex of $75-80 \mathrm{kDa}\left(K_{\mathrm{a}}=3-9 \times 10^{8}\right.$ $\mathrm{M}^{-1}$ ) with limited capacity (20-150 $\mathrm{ng} / \mathrm{ml}$ ) (Barnard et al., 1985; Baumann et al., 1986; Baumann, 1991; Tar et al., 1990). The present study only detected hGH-BP complexes of high molecular weight 130-150 kDa. High molecular weight GH-BP has also been detected in human serum. These BPs bind hGH with very low affinity $\left(10^{6}-10^{5} \mathrm{M}^{-1}\right)$ and high capacity (between 2 and $15 \mu \mathrm{g} / \mathrm{ml}$ ) and are thought not to be related to the GH receptor (Baumann and Shaw, 1990; Tar et al., 1990). However, there are high molecular weight complexes in murine serum (Smith and Talamantes, 1987) and also in the culture medium of cells transfected with rabbit GH-BP cDNA (Edery et al., 1993). These data suggest that circulating multimers of GH-BP may arise after proteolysis of the membrane bound $\mathrm{GH}$ receptor. Therefore, it is possible that the 130- and 150-kDa bands observed after cross-linking or HPLC elution in the present study may correspond to dimers of complexed BP with one or two molecules of hGH (22 kDa). The demonstration that mAb263 monoclonal antibody to the $\mathrm{GH}$ receptor is able to immunoprecipitate the hGH-BP complex supports the idea that tGH-BP may represent the extracellular domain of the $\mathrm{GH}$ receptor in trout serum.

Two mechanisms for generation of the GH-BPs have been shown. GH-BP may arise from proteolytic cleavage of the membrane receptor (Baumann, 1991; Sotiropoulos et al., 1993) encoded by a single transcript of 4.5 $\mathrm{kb}$ (Leung et al., 1987) or by alternative splicing of a primary transcript which gives rise to two different mRNAs (Baumbach et al., 1989). One mRNA of $4.5 \mathrm{~kb}$ 

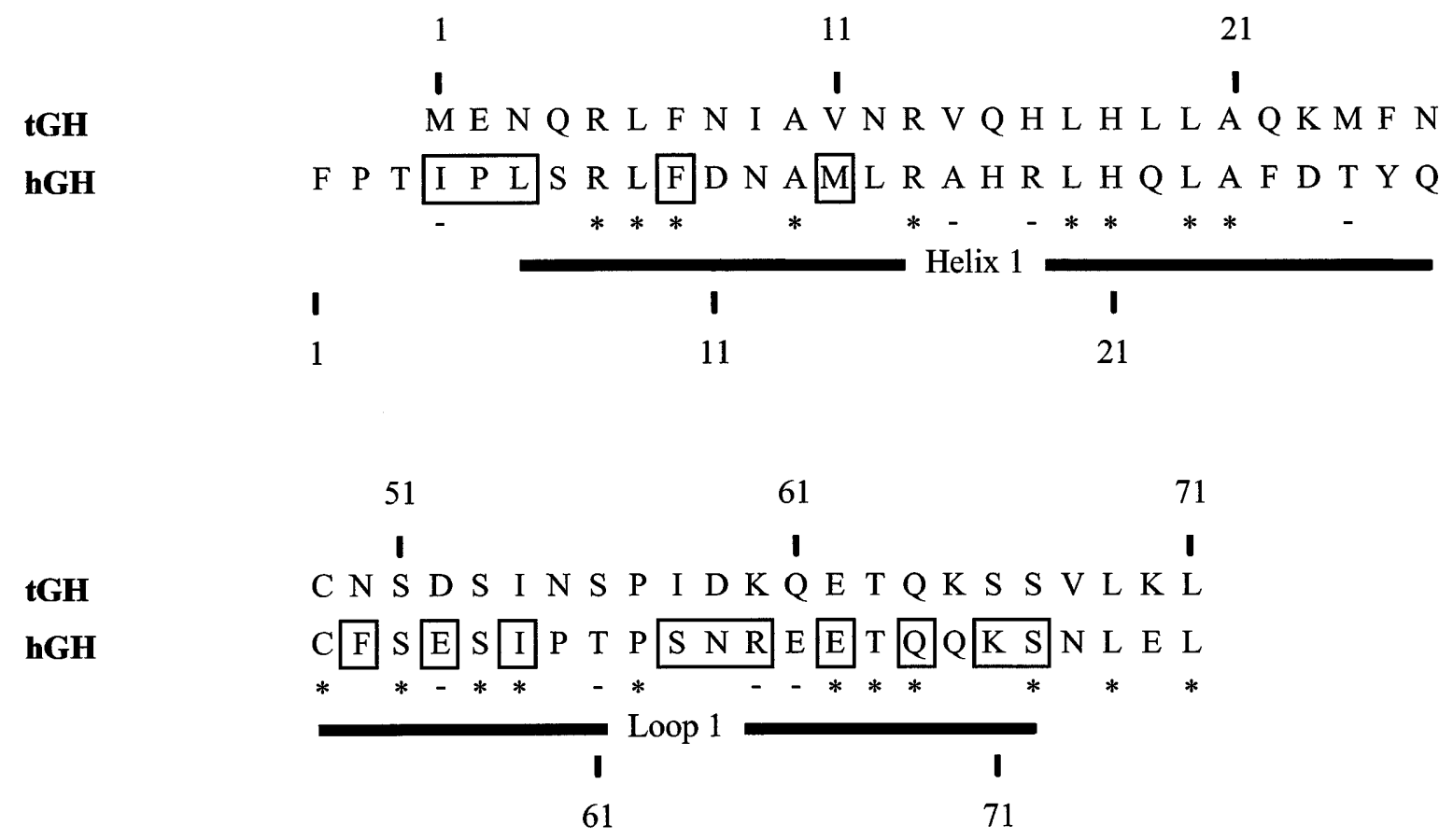

tGH hGH

\section{I}

\section{I}

N Y E L L A C F K K D M H K V E T Y L T V A K C R K Y L E A N

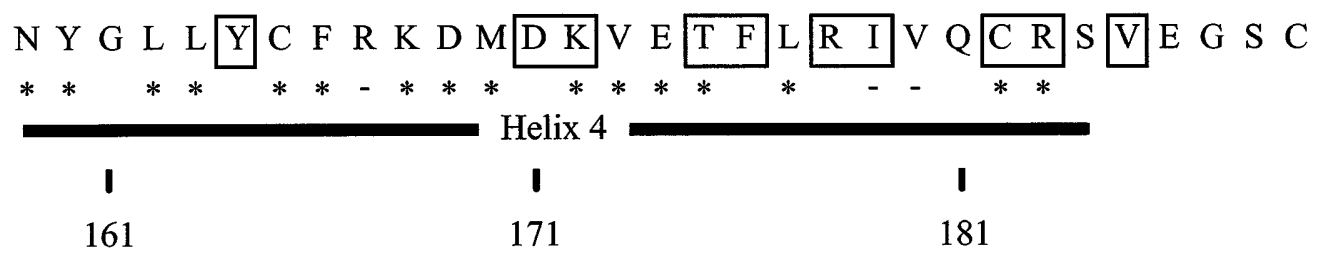

FIG. 5. Comparison of the binding site 1 determinants of hGH and $\mathrm{tGH}$. The three regions constituting the binding site 1 of hGH (N terminus, second half of loop 1 and $\mathrm{C}$ terminus) are aligned. Residue numbering above and below the sequences refer to tGH and hGH, respectively. Residues involved in hGH/hGHBP interactions are from Cunningham and Wells (1989). Residues reducing the binding by more than twofold are boxed. $\left.{ }^{*}\right)$ identical amino acids; $(-)$ conserved amino acids.

encodes the membrane receptor and another of $1.2 \mathrm{~kb}$ encodes the GH-BP, i.e., the extracellular domain of the $\mathrm{GH}$ receptor lacking the transmembrane and cytoplasmic domains. Molecular cloning of the GHR cDNA should help clarify the mechanism(s) of GH-BP generation in trout.

The role of GH-BP in serum is uncertain in mammals. GH in this complexed form has an increased half-life compared to free hormone (Baumann, 1991). Thus, the hormone bound to the BP is protected from degradation and represents a hormone "reservoir" in serum. However, GH-BP production by individual tissues could alter independently their own sensitivity to circulating $\mathrm{GH}$ or could be regulated under certain physiological conditions, thus modulating GH action.

No kinetic studies have been performed on circulating hGH in rainbow trout. However, in relation to the higher affinity of the BP to hGH relative to $\mathrm{tGH}$ found in the present study, it is of interest to note that hGH is more potent than salmon $\mathrm{GH}$ in stimulating thyroid 
hormone 5'-deiodination in trout liver (Mac Latchy and Eales, 1990; Mac Latchy et al., 1992). Indeed, the interplay between thyroid hormones deiodination and $\mathrm{GH}$ is known to be critical for seawater survival of rainbow trout during the early phase of acclimatization (Lebel and Leloup, 1992).

Changes in GH-BP levels in rainbow trout serum during the time course of seawater acclimatization could reflect the up-regulation of hepatic GH receptors. An increased total binding sites for GH occurs 4 days after seawater transfer (Sakamoto and Hirano, 1991a). Circulating GH is significantly increased $24-48$ $h$ following seawater transfer and then decreases, reaching levels found in freshwater thereafter (Sakamoto et al., 1990, 1991). Furthermore, 4 days after seawater transfer, both GH metabolic clearance and secretion rate have been shown to be five times higher than those found in freshwater adapted trout (Sakamoto et al., 1990). No information is available on GH receptor turnover in fish. Thus, the low binding affinity of this circulating BP-GH for $\mathrm{tGH}$ does not necessarily reflect a physiological function in term of plasma $\mathrm{GH}$ clearance. Conversely, it may be that the increased clearance of plasma $\mathrm{GH}$ is related to its role played on GH receptor turnover at the cellular level; thus after binding there is an increased GH receptor breakdown in seawater transferred rainbow trout.

Taken together, these results support a biological link between increased circulating GH and a related GH-BP in blood during seawater adaptation in rainbow trout. However, whereas GH binding activity seems to be linked to GH and GH receptor evolution, further studies are needed to assess the regulation and function of this GH-BP in salmonid.

\section{ACKNOWLEDGMENTS}

F.S. and I.M. contributed equally to this paper and are considered as co-first authors. The authors are grateful to Professor H. A. Bern, University of California (Berkeley, CA) for his continued interest and encouragement during the course of the study. We thank Vincent Goffin for helpful discussion. We are indebted to Christine Kayser for expert technical assistance and to Claudine Coridun for expert secretarial assistance. This study was supported by the National Museum of Natural History (Paris) and the Institut National de la Santé et de la Recherche Médicale.

\section{REFERENCES}

Barnard, R., Bundesen, P. G., Rylatt, D. B., and Waters, M. J. (1985). Evidence from the use of monoclonal antibody probes for structural heterogeneity of the growth hormone receptor. Biochem. J. 231, 459-468.

Baumann, G. (1991). Growth hormone heterogeneity: Genes, isoformes, variants, and binding proteins. Endocr. Rev. 12, 424-449.

Baumann, G., and Shaw, M. A. (1990). A second, lower affinity growth hormone-binding protein in human plasma. J. Clin. Endocrinol. Metab. 70, 680-686.

Baumann, G., Stolar, M. W., Amburn, K., Barsano, C. P., and DeVries, B. C. (1986). A specific growth hormone-binding protein in human plasma: initial characterization. J. Clin. Endocrinol. Metab. 62, 134-141.

Baumbach, W. R., Horner, D. L., and Logan, J. S. (1989). The growth hormone-binding protein in rat serum is an alternatively spliced form of the rat growth hormone receptor. Genes Dev. 3, 1199-1205.

Calduch-Giner, J. A., Sitjà-Bobadilla, A., Alvarez-Pellitero, P., and Pérez-Sánchez, J. (1997). Growth hormone as an in vitro phagocyteactivating factor in the gilthead sea bream (Sparus aurata). Cell Tissue Res. 287, 535-540.

Clarke, W. C., Farmer, S. W., and Hartwell, K. M. (1977). Effects of teleost pituitary growth hormone on growth of Tilapia mossambica and on growth and seawater adaptation of sokeye salmon (Oncorhynchus nerka). Gen. Comp. Endocrinol. 33, 174-178.

Collie, N. L., Bolton, J. P., Kawauchi, H., and Hirano, T. (1989). Survival of salmonids in seawater and the time frame of growth hormone action. Fish Physiol. Biochem. 7, 315-321.

Cunningham, B. C., and Wells, J. A. (1989). High-resolution epitope mapping in hGH-receptor interactions by alanine-scanning mutagenesis. Science 244, 1081-1084.

Davis, S. L., Graf, M., Morrison, A., Hall, T. R., and Swift, P. J. (1992). Identification and partial purification of serum growth hormone binding protein in domestic animal species. J. Anim. Sci. 70, 773-780.

Edery, M., Rozakis-Adcock, M., Goujon, L., Finidori, J., LévyMeyrueis, C., Paly, J., Djiane, J., Postel-Vinay, M. C., and Kelly, P. A. (1993). Lack of hormone binding in COS-7 cells expressing a mutated growth hormone receptor found in Laron dwarfism. J. Clin. Invest. 91, 838-844.

Goffin, V., Shiverick, K. T., Kelly, P. A., and Martial, J. A. (1996). Sequence-function relationships within the expanding family of prolactin, growth hormone, placental lactogen and related proteins in mammals. Endocr. Rev. 17, 385-410.

Gray, E. S., Young, G., and Bern, H. A. (1990). Radioreceptor assay for growth hormone in coho salmon (Oncorhynchus kisutch) and its application to the study of stunting. J. Exp. Zool. 256, 290-296.

Laemmli, U. K. (1970). Cleavage of structural proteins during the assembly of the head bacteriophage T4. Nature 227, 680-685.

Lebel, J. M., and Leloup, J. (1992). La triodothyronine est nécessaire à l'acclimatation à l'eau de mer de la truite fario (Salmo trutta) et arc en ciel (Oncorhynchus mykiss). C. R. Acad. Sci. 314, 461-468. 
Lesniak, M. A., Roth, J., Gorden, P., and Gavin, J. R. (1973). Human growth hormone radioreceptor assay using cultured human lymphocytes. Nature (New biol.) 241, 20-22.

Leung, D. W., Spencer, S. A., Cachianes, G., Hammonds, R. G., Collins, C., Henzel, W. J., Barnard, R., Waters, M. J., and Wood, W. I. (1987). Growth hormone receptor and serum binding protein: purification, cloning, and expression. Nature 330, 537-543.

Mac Latchy, D. L., and Eales, J. G. (1990). Growth hormone stimulates hepatic thyrosine 5 '-monodeiodinase activity and 3,5,3'triiodothyronine levels in rainbow trout (Samo gairdneri). Gen. Comp. Endocrinol. 78, 164-172.

Mac Latchy, D. L., Kawauchi, H., and Easles, J. G. (1992). Stimulation of hepatic $5^{\prime}$-deiodinase activity in rainbow trout (Oncorhynchus mykiss) by pacific salmon growth hormone. Comp. Biochem. Biophys. 101, 689-691.

Mercier, L., Rentier-Delrue, F., Swennen, D., Lion, M., Le Goff, P., Prunet, P., and Martial, J. A. (1989). Rainbouw trout prolactin cDNA cloning in Escherichia coli. DNA 8, 119-125.

Munson, P. J., and Rodbard, O. (1980). Ligand: A versatile computerized approach for characterization of ligand binding systems. Anal. Biochem. 107, 220-239.

Postel-Vinay, M. C. (1996). Growth hormone- and prolactin-binding proteins: Soluble forms of receptors. Horm. Res. 45, 178-181.

Rand-Weaver, M., and Kawauchi, H. (1993). In "Biochemistry and Molecular Biology of Fishes" (P. Hochachka and T. Mammsen, Eds.), pp. 39-56. Elsevier, Amsterdam.

Rand-Weaver, M., Swanson, P., Kawauchi, H., and Dickhoff, W. W. (1991). Somatolactin, a novel pituitary protein: purification and plasma levels during reproductive maturation of coho salmon. J. Endocrinol. 133, 393-403.

Rentier-Delrue, F., Swennen, D., Mercier, L., Lion, M., Benrubi, O., and Martial, J. A. (1989a). Molecular cloning and characterization of two forms of trout growth hormone cDNA: Expression and secretion of tGH-II by E. coli. DNA 8, 109-117.

Rentier-Delrue, F., Swennen, D., Prunet, P., Lion, M., and Martial,
J. A. (1989b). Tilapia prolactin: Molecular cloning of two cDNAs and expression in Escherichia coli. DNA 8, 261-270.

Sakamoto, T., and Hirano, T. (1991). Growth hormone receptors in the liver and osmoregulatory organs of rainbow trout: characterization and dynamics during adaptation to seawater. J. Endocrinol. 130, 425-433.

Sakamoto, T., Iwata, M., and Hirano, T. (1991b). Kinetic studies of growth hormone and prolactin during adaptation of coho salmon, Oncorhynchus kisutch, to different salinities. Gen. Comp. Endocrinol. 82, 184-191.

Sakamoto, T., Ogasawara, T., and Hirano, T. (1990). Growth hormone kinetics during adaptation to a hyperosmotic environment in rainbow trout. J. Comp. Physiol. B 160, 1-6.

Salacinski, P., McLean, C., Sykes, J., Clement-Jones, V., and Lowry, P. (1981). Iodination of proteins, glycoproteins and peptides using a solid phase oxidizing agent, 1,3,4,6-tetrachloro-3a,6a-diphenyl glycoluryl (Iodogen). Anal. Biochem. 117, 136-146.

Smith, W. C., and Talamantes, F. (1987). Identification and characterization of a heterologous population of growth hormone receptors on mouse hepatic membranes. J. Biol. Chem. 262, 2213-2219.

Sotiropoulos, A., Goujon, L., Simonin, G., Kelly, P. A., Postel-Vinay, M. C., and Finidori, J. (1993). Evidence for generation of the growth hormone-binding protein through proteolysis of the growth hormone membrane receptor. Endocrinology 132, 1863-1865.

Swennen, D., Rentier-Delrue, F., Auperin, B., Prunet, P., Flik, G., Wendelaar, B. S., Lion, M., and Martial, J. A. (1991). Production and purification of biologically active recombinant tilapia (Oreochromis niloticus) prolactins. J. Endocrinol. 131, 219-227.

Tar, A., Hocquette, J. F., Souberbielle, J. C., Clot, J. P., Brauner, R., and Postel-Vinay, M. C. (1990). Evaluation of the growth hormonebinding proteins in human plasma using HPLC-gel filtration. J. Clin. Endocrinol. Metab. 71, 1202-1207.

Yao, K., Niu, P. D., Le Gac, F., and Le Bail, P. Y. (1991). Presence of GH specific binding sites in rainbow trout (Oncorhynchus mykiss) tissues: Characterization of the hepatic receptor. Gen. Comp. Endocrinol. 81, 72-82. 